\title{
Initiative aiming to introduce children to maps in Kenya
}

\author{
Catherine M. Njore ${ }^{a,}{ }^{*}$, Charles Mwangi Kimari ${ }^{b}$, Kuria Thiong'o $^{a}$ \\ a. Institute of Geomatics, GIS and Remote Sensing (IGGReS) Dedan Kimathi University of Technology, cnjore@gmail.com, \\ kuria.thiongo@dkut.ac.ke \\ b. Think Community Based Organization, P. O. Box 38 -Mweiga, Nyeri, charles2kimari@gmail.com
}

* Corresponding author

\begin{abstract}
:
The age at which one is introduced to cartography and map making skills has been identified as a major factor in creating interest and awareness in mapping, more so when incorporated in the education system. Additionally, participation of children in various cartographic arts and maps competitions develops their cognitive knowledge and skills. Despite this information, Kenya continues to lag behind in the incorporation of qualified cartographic products into the education curriculum. The objective of this project therefore was to sensitize the various education stakeholders in the country on the need to develop childrens' cognitive skills and abilities at an early stage in their life. The project, which is at its initial stage, formulated under a book club called "ThinkWords" mainly targets primary school children (4-10 years) and is currently working with one of the schools based in Nyeri County, Kenya as a pilot project. The children are engaged in various activities which include maps and their uses. Currently the "ThinkWords" club has a membership of 50, which is inclusive of children and their teachers. The ultimate goal of the project is to convince the relevant education stakeholders in the country on the importance of introducing cartography in schools, by sharing the children's work with the relevant government authorities and stakeholders on need of children themed maps in terms of symbology. The project is then envisioned to be rolled out to other parts of the country and eventually lead to the inclusion of cartographic training skills into the education system.
\end{abstract}

Keywords: Thematic maps, Atlas, children, cartography

\section{Introduction}

Over the years, the application and use maps has been on the increase, propelled mainly by the technological advancement that has enabled the professional presentation of maps with spatial bases (Blades \& Spencer, 1986). However, very minimal attention continues to be given to the proper map making. In Kenya, on the average children get to interact with maps while in high school and this interaction is limited to topographic maps interpretation. Studies by (Buğdayci \& Selvi, 2018) and (Bluestein \& Acredolo, 1979) recommended that that creating an interest in maps and their uses to children at an early age while ensuring that there is no misunderstanding and misinterpretation, is vital (Buğdayci \& Selvi, 2018) Activities prepared using information on an environment that the children are used to makes it easy to slowly include the map making concept. Asking the children to create maps of their current environment motivates them since they have a sense of ownership to the map.

Brazil, Bulgaria, Hungary and Portugal are notable success stories where qualified cartographic products have been incorporated into the education system after the countries' noting of the poor design of the maps used in their education systems.(Buğdayci \& Selvi, 2018) The concept capitalizes on the children's varying level of understanding, with the younger groups (4-6 years) appreciating more colourful maps with real feature pictorial symbols whilst the older groups working well with other map symbols. The ideology is that nurturing children to map use early enough will lead to future appreciation of maps and create a rise to proper cartographic skills in their map application in their different fields (Buğdayci \& Selvi, 2018)

Anderson, (2003) identified the school atlas not only as one of the most popular commercial map products for children, but also as an important mapping tool. Taking into account subjects content that make use of maps can assist in designing relevant symbols for the atlases that would be effective to the different ages of children, namely: children picture atlas for ages 4-6; atlas for midschool for ages 7-9; upper primary atlas for ages 10-13. This would enable the relevant ages map activities in each level. And this being a problem in many countries there is need for cartographers to come together and formulate a solution to the need of better maps for children. (Y Artemiev, 1998)

The author initiated a project whose main objective was to develop cartographic interest in primary school going children. The objective of this project was to build on the various preceding success stories where cartography has been incorporated into the children education system. The project was initiated in Nyeri County of Kenya as a Pilot. The project is formulated under a book club called 
"ThinkWords" whose membership is children between the ages of 4 and 10 years. The children are engaged in various mapping activities that aid in developing their cognitive skills and abilities at an early stage in their life. The children's maps are then shared on various platforms, including global mapping competitions. It is through these interaction platforms that the project seeks to create awareness to the relevant education stakeholders in the country on the importance of introducing cartography in schools.

\section{Methodology}

Twenty children were engaged in mapping activities to assess their level of understanding and as such use the results of their activities to plan for the different age groups map tasks.

Each child was asked to draw "three" maps which were assessed by professional cartographers and final assessment was by a cartographer based at the Ministry of Lands and Physical planning.

The assignments were prepared for three age groups: 4-6 years; $7-8$ years; $9-10$ years. The $4-6$ year olds were tasked with drawing a map of their classrooms, the 7-8 year olds were asked to draw a map of their school, while the 9-10 years asked to draw maps showing their way from home, through the town to their school. The 9-10 years old presentation was quite extensive as one particular case from title to key had much detail. Drawings were prepared and assessed. In every attempt, their work got better after every assessment and this identified positive progress. Not all of the twenty children were able to grasp the concept. Instead of presenting questions to the children, they were allowed to ask the questions, which were addressed as they progressed.

The level of difficulty in understanding the maps was captured in their questions which included:

- Why are the colours used dull? (5year old)

- Are there maps showing details of the other planets? (8 year old)

- Why are extra notes so few or missing? (9year old after viewing a continents page from an atlas)

These questions guided the planning direction to be taken and the points to concentrate on.

\subsection{Results}

Table 1 summarizes the results from the three groups of children. The 4-5 years age group could understand what a map is and draw them. The 7-8 years age group knew who a cartographer is, could draw a map of the school as well as the continents observed from a globe. The 9-10 years age group were familiar with cartographic and mapping terminologies. They could define terms such as a map title, key, map scale, map grid and coordinate, and the north arrow. They could understand the scale element, since as they drew the maps of their route from home to school, they varied building sizes with smaller rectangles depicting far away buildings while larger rectangles depicted close range buildings. Explaining coordinates and the north arrow was however the greatest challenge.

\begin{tabular}{|c|c|c|}
\hline Age & $\begin{array}{l}\text { Assessed } \\
\text { Concepts }\end{array}$ & Deliverables \\
\hline $\begin{array}{l}4- \\
\text { 6years }\end{array}$ & $\begin{array}{l}\text {-understand what } \\
\text { a map is } \\
\text { - can draw a map } \\
\text { of their classroom } \\
\text {-knows continents }\end{array}$ & $\begin{array}{l}\text {-drawn maps are filed } \\
\text { in the book club records } \\
\text {-puzzles using tablets } \\
\text { on maps are still } \\
\text { interesting to them }\end{array}$ \\
\hline $\begin{array}{l}7-8 \\
\text { years }\end{array}$ & $\begin{array}{l}\text {-understand what } \\
\text { a cartographer } \\
\text { does } \\
\text {-can draw my } \\
\text { school map } \\
\text {-can draw the } \\
\text { globe with } \\
\text { continents }\end{array}$ & $\begin{array}{l}\text {-maps filed } \\
\text {-interested in more } \\
\text { ways to represent } \\
\text { his/her maps }\end{array}$ \\
\hline $\begin{array}{l}9-10 \\
\text { years }\end{array}$ & $\begin{array}{l}\text {-comfortable } \\
\text { defining } \\
\text { cartography and } \\
\text { maps } \\
\text {-can show } \\
\text { creatively large } \\
\text { areas around } \\
\text { them(school, } \\
\text { home, town) }\end{array}$ & $\begin{array}{l}\text {-doing some writing on } \\
\text { places visited and } \\
\text { features seen. } \\
\text {-interested in longitudes } \\
\text { and latitudes and class } \\
\text { teacher engaged in } \\
\text { explaining the same. }\end{array}$ \\
\hline
\end{tabular}

Table 1. ThinkWords book club map activities progress

Figure 1 is a classroom map prepared by a 5year old after explaining how one views the room from a height above the roof looking down, a concept from (Matkin, 1970) Figure 2 was a progress assessment by a 6 year old preparing for a mapping competition. Figure 3 and 4 are from an 8-year-old who drew a school map and also an attempt for the competition respectively. Figure 6 is an enlargement of figure 5 where a 10year old was asked to show the way from home to school through the small town. 


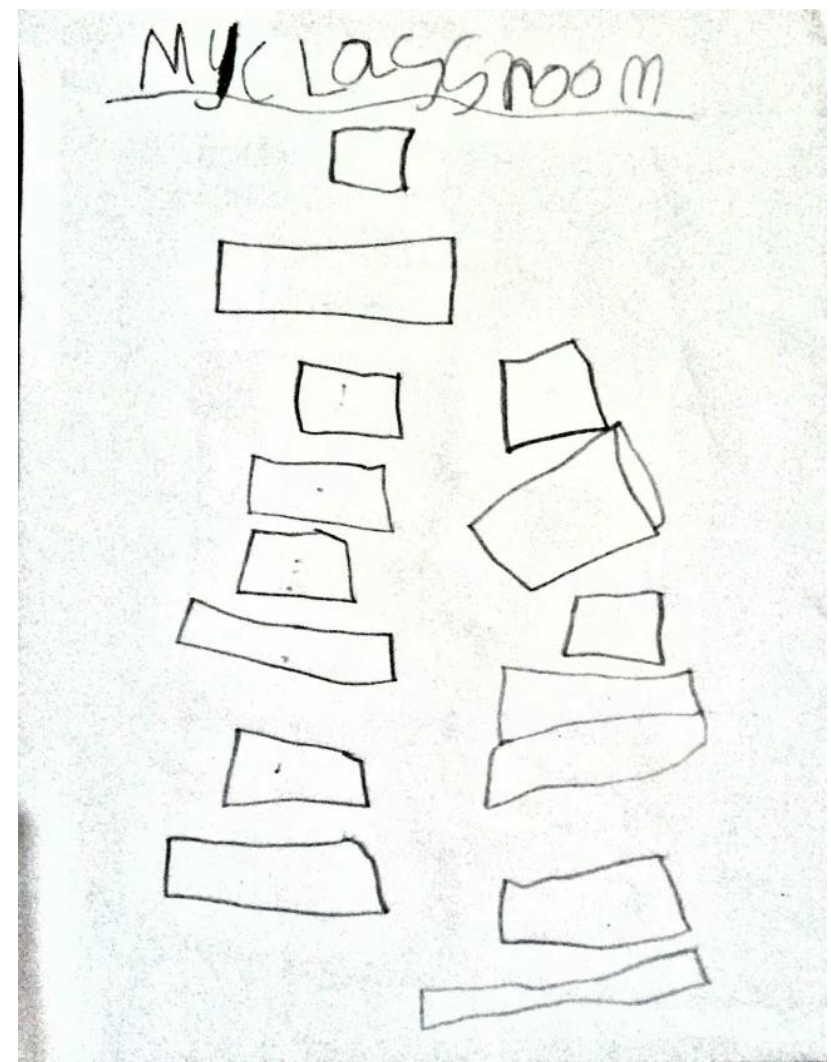

Figure 1 . My classroom map by a 5year old.

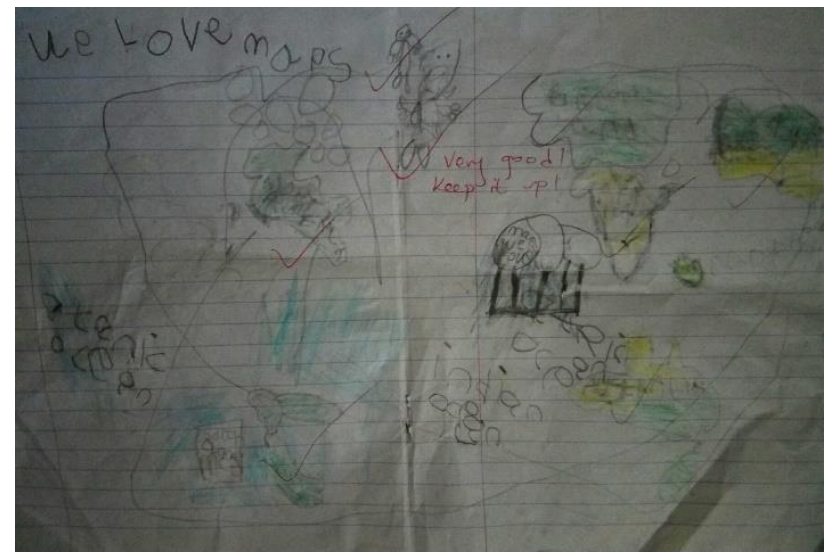

Figure 2. "We love maps" by Matthew Pio, 5years.

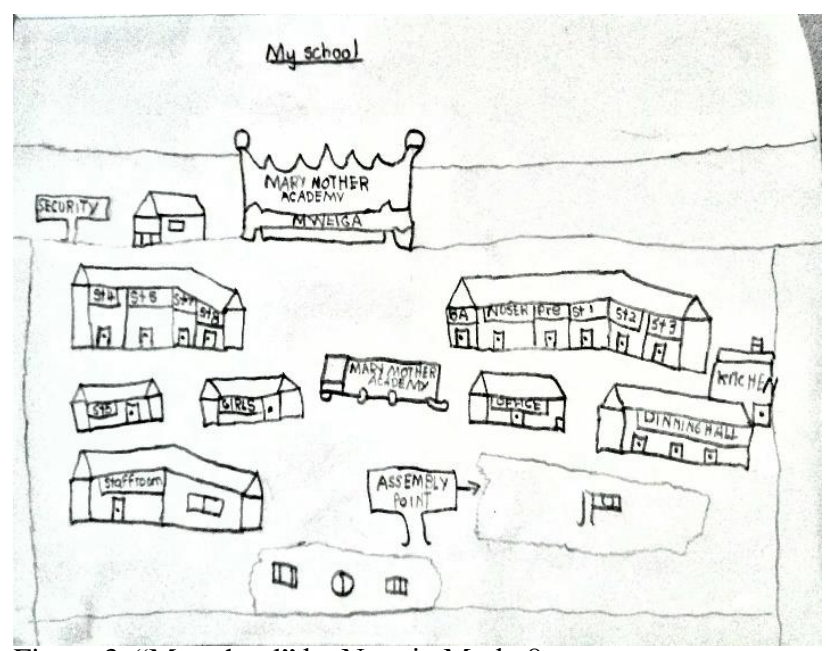

Figure 3. "My school" by Ngunju Mark, 8years.

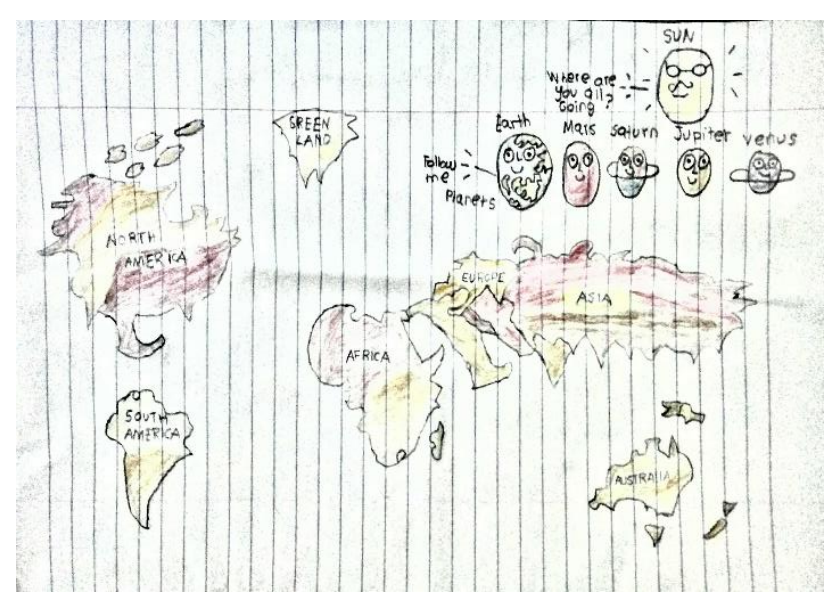

Figure 4. "We love maps" by Ngunju Mark, 8 years.

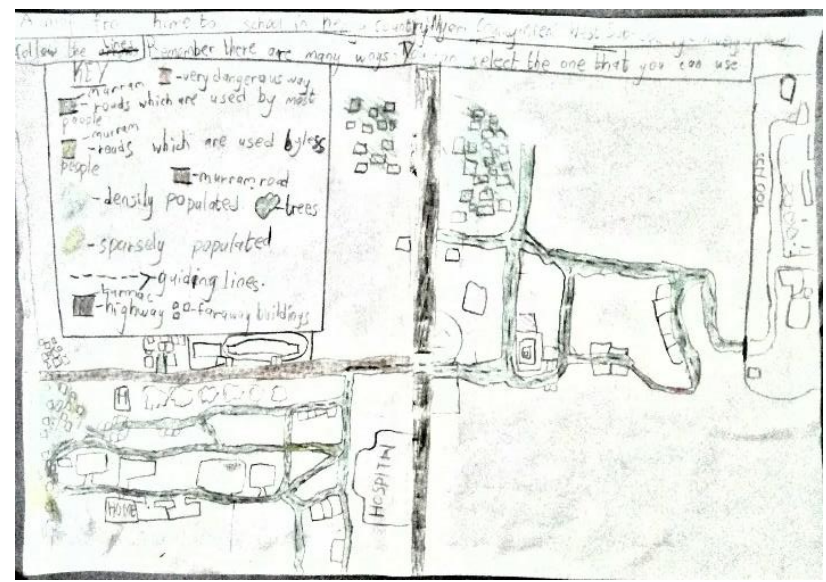

Figure 5. Home to school map by Martin Njenga 10years. 


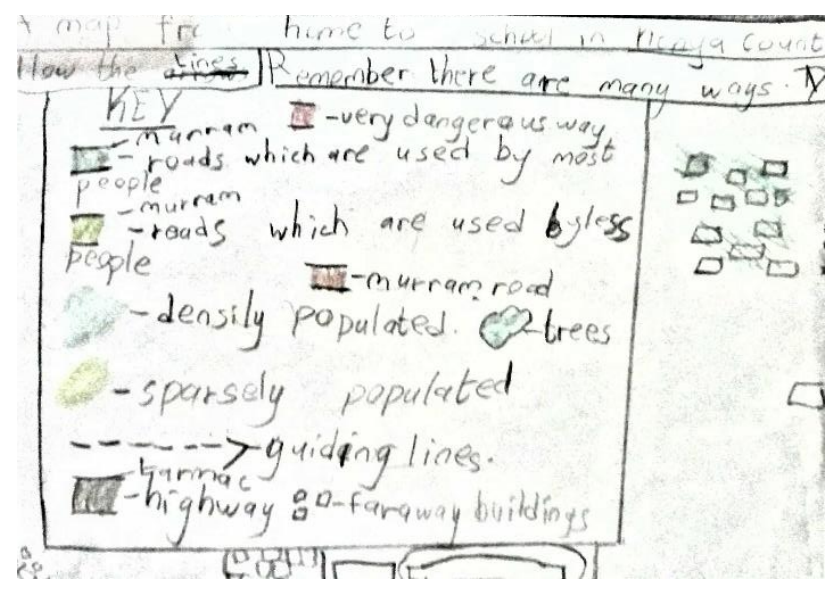

Figure 6. Zoom in to figure 5

\section{Conclusions}

There has been an increase in the clubs membership, with the current number standing at 99 . This can be attributed to the increased awareness by the children, their teachers, and parents on cartography. Selected maps prepared by the children have since been submitted to regional and international map competitions. This is despite the challenges encountered which include lack of proper drawing materials, limited time, funds and support from the various stakeholders. This project provides evidence that with the right support from the relevant education stakeholders in the country, the interest in maps and cartography can be developed in children, particularly with the expansion of the project to other parts of the country, or its inclusion into the curriculum.

\subsection{Acknowledgments}

The author thanks in a special way Mary Mother Academy in Mweiga - Nyeri County for allowing the project research to be carried out at the school.

\section{References}

Anderson, J. M. (2003). Cartography and Children - At the Dawn of its Development. 11.

Artemiev, Y. (1998). Problems in Cartography for Children in Russia. Proc. Joint ICA Seminar, Wroclaw, WarsawLaski, Poland, 49-52.

Blades, M., \& Spencer, C. (1986). Map Use by Young Children. Geography, 71(1), 47-52. Retrieved from JSTOR.

Bluestein, N., \& Acredolo, L. (1979). Developmental
Development,

$50(3)$

691-697.

https://doi.org/10.2307/1128934

Buğdayci, İ., \& Selvi, H. Z. (2018). Designing and Producing Maps and Similar Map Products for Primary School Pupils o Analogue and Digital Media. The Journal of Academic Social Science, 6(65), 104-110.

Matkin, R. . (1970). Maps and Map Reading. Faber and Faber Limited.

Changes in Map-Reading Skills. Child 